\title{
Genetic control of the vertical transmission of a cytoplasmic sex factor in Armadillidium vulgare Latr. (Crustacea, Oniscidea)
}

\author{
THIERRY RIGAUD \& PIERRE JUCHAULT \\ Université de Poitiers, Laboratoire de Biologie Animale, URA CNRS 1452, Génétique et Biologie des Populations de \\ Crustacés, 40, Avenue du Recteur Pineau, F-86022 Poitiers Cedex, France
}

\begin{abstract}
In Armadillidium vulgare, sex determination may be under the control of a maternally transmitted endosymbiotic bacteria $(F)$, which reverses genetic males $(\mathrm{ZZ})$ into functional neo-females $(\mathrm{ZZ}+\mathrm{F})$. These neo-females generally produce highly female-biased progenies (thelygenous progenies $=\mathrm{TF}$ ) but a few of them produce highly male-biased progenies (arrhenogenous progenies $=\mathrm{ARF}$ ). These TF and ARF traits are selected, and the inoculation of F bacteria in different categories of females shows that these traits are genetically controlled by the host and do not depend on different bacterial strains. By pairing males from the ARF strain with genetic females (WZ), it can be seen that the ARF trait is unrelated to the effect of an autosomal masculinizing gene $(M)$. In fact, the ARF trait appears to be under the control of a polygenic system, the genes influencing the sex ratio indirectly via their effects on the cytoplasmic factor (resistance genes).
\end{abstract}

Keywords: endosymbiote, extrachromosomic sex factors, genetic control, sex ratio, Wolbachialike.

\section{Introduction}

In the terrestrial Isopod Armadillidium vulgare (pillbug), the basis of sex determination is genetic: the males are homogametic $(\mathrm{ZZ})$ and the females heterogametic (Juchault \& Legrand, 1972). These genetic females produce broods with equal numbers of males and females (sex ratio=1:1). However, in several natural populations, sex ratios are often female biased (Juchault et al., 1980; Juchault \& Legrand, 1981a,b). It has been shown in such populations that sex determination of most individuals is under the control of extrachromosomal sex factors which override the sexual chromosomes' effect (Juchault \& Legrand, 1981a,b).

One of these factors (named F) has been characterized as a feminizing symbiotic endocellular bacteria carried by females, located in any tissue, but especially in the oocytes (Martin et al., 1973). This bacteria recalls the Rickettsiales (Weiss, 1982), and more particularly the Wolbachia sp. observed in different species of mosquito (Irvin-Bell, 1974; Larsson, 1983). In strains that harbour $\mathrm{F}$, all individuals are genetic males $(\mathrm{ZZ})$ and female sexual differentiation only occurs in the presence of the feminizing factor
(Juchault et al., 1980a). Thus, these females are neofemales $(Z Z+F)$. As bacteria are only transmitted maternally, their transmission rate determines the male rate in progenies, as uninfected oocytes evolve according to their $\mathrm{ZZ}$ genotype. Tissue implants from neofemales $\mathrm{ZZ}+\mathrm{F}$, or injection of crushed tissues transform genetic males into sterile intersexes and genetic females into thelygenous females (females producing female biased progenies) (Legrand \& Juchault, 1970). This feminizing sex factor could be called a cytoplasmic sex factor according to Bull's definition (Bull, 1983). Such a particular sex-determining mechanism has been observed in both amphipoda Orchestia gammarellus and Gammarus duebeni, in which cytoplasmic factors are related to Protozoa (Bulnheim, 1978; Ginsburger-Vogel et al., 1980). In the haplodiploid insect Nasonia vitripennis, sex is suspected to be under the control of cytoplasmic micro-organisms (Werren et al., 1981; Skinner, 1983). In $A$. vulgare, a second feminizing factor (f), with effects and transmission mode close to those of $F$, is known to exist. However, neo-females that harbour $f$ are sensitive to the masculinizing action of the androgenic hormone, while $\mathrm{ZZ}+\mathrm{F}$ neo-females are unaffected. Some genetical and physiological data 
suggest that factor $f$ could be a segment of $F$ bacterial DNA integrated in the Isopod genome (Legrand \& Juchault, 1984).

A majority of $\mathrm{ZZ}+\mathrm{F}$ neo-females regularly produce highly female-biased progenies (thelygenous progenies $=\mathrm{TF}$ ), consequent to the high maternal transmission of the sexual factor (Juchault \& Legrand, 1981a). However, a few $Z Z+F$ neo-females produce progenies with low rates of females (arrhenogenous progenies). Two kinds of arrhenogenous progenies are observed: (i) progenies with rare or no intersexes (ARF progenies) and (ii) progenies in which the intersex rate approaches or exceeds 50 per cent (ARFi). A masculinizing autosomal factor $(\mathbf{M})$, capable of thwarting the $\mathrm{F}$ feminizing effect, is responsible for ARFi progenies (Legrand et al., 1974; Juchault \& Legrand, 1976). Intersexes in these progenies show various phenotypes between male and female, and these phenotypes result from the conflict between the $\mathrm{M}$ gene and the $\mathrm{F}$ cytoplasmic factor (i.e. an incomplete feminization by $F$ ).

The aim of this paper is to determine the ARF trait. We first investigated whether the masculinizing gene $M$ is present in the ARF strain, then if there is a difference in virulence between $F$ bacteria harboured in the TF and ARF strains. TF and ARF traits were selected and females were inoculated with bacteria from TF and ARF strains.

\section{Materials and methods}

The animals were from two strains sampled in nature and reared in the Poitiers laboratory for many years. $\mathrm{ZZ}+\mathrm{F}$ neo-females are derived from a population sampled in Niort, while males and genetic females are from a population sampled in Nice. In order to obtain a rapid onset of reproduction and two or three broods per generation, all breeding took place at $20^{\circ} \mathrm{C}$ and over a 'long day' photoperiod (LD 18:6) (Mocquard et al., 1989). Under these conditions, one generation was obtained per year.

\section{Selection of the thelygenous (TF) and arrhenogenous (ARF) traits in neo-females}

Neo-females of the parental generation were chosen in an intersexless strain, which was presumed to be free of $M$. For each generation, 15 neo-females from pure TF broods (with 0 per cent of males) or strongly ARF (with more than 70 per cent of males) were used as mothers for the following generation. The fathers were from the Nice population. The sex of offspring was determined for each brood after sexual differentiation and the young females were separated from their brothers in order to avoid sib-breeding. The offspring from all broods of a single mother were added to obtain the progeny of this female.

Two criteria were used to compare progenies of the different categories of females: (i) the mean male ratio per progeny (MMR), which gave the mean rate of offspring uninfected by $F$ bacteria and (ii) the mean intersex ratio per progeny (MIR), for the mean rate of partial feminization among offspring infected by $F$ (Rigaud et al., 1991). In order to obtain a MMR for progenies of one generation of selection or one category of females, each progeny was characterized as a point with $X$ absciss $X=$ number of descendants in the progeny) and $Y$ ordinate $Y=$ number of males in the progeny). The linear regression line adjusted to these values and which passes through the origin $X=Y=0$ ) has as a slope the ratio $\Sigma Y / \Sigma X$, which represents the MMR (Rigaud et al., 1991). The standard error for this value is that calculated for the slope. The MIR is calculated in the same way but in this case, $X=$ number of young infected with $F$ bacteria in the progeny (= number of descendants - number of males), and $Y=$ number of intersexes in the progeny. The MMR and MIR were then compared with an analysis of covariance and the Snedecor $F$-test.

To establish the presence or absence of the $\mathrm{M}$ gene in the ARF progenies, males from the $F_{6}$ selection generation were paired with genetic females $(W Z)$. It is known that $M$ is transmitted by males and that consequently 50 per cent of $\mathrm{WZ}$ females in their broods are reversed into neo-males or into neo-males with female genital apertures (intersexes) when masculinization by $M$ is delayed (Legrand et al., 1974).

\section{Inoculation of bacteria from TF and ARF strains into different categories of females}

Ovaries from $10 \mathrm{TF}$ and $10 \mathrm{ARF}$ neo-females of the $\mathrm{F}_{6}$ selection generation were crushed separately in $1 \mathrm{ml}$ of physiological serum. One microlitre of each solution was inoculated (after filtration under $1.2 \mu \mathrm{m}$ pores) into 15 genetic females and into 15 ARF neo-females, also from the $F_{6}$ generation. The inoculated females were paired, and the MMR in their progenies was calculated in order to evaluate the $\mathrm{F}$ transmission rate in their new host.

\section{Results}

\section{Selection of TF and ARF traits}

Males from the Nice population were paired over seven generations with neo-females from pure thelygenous progenies. The TF trait was conserved in each generation (Fig. 1a), but pure thelygeny (100 per cent 

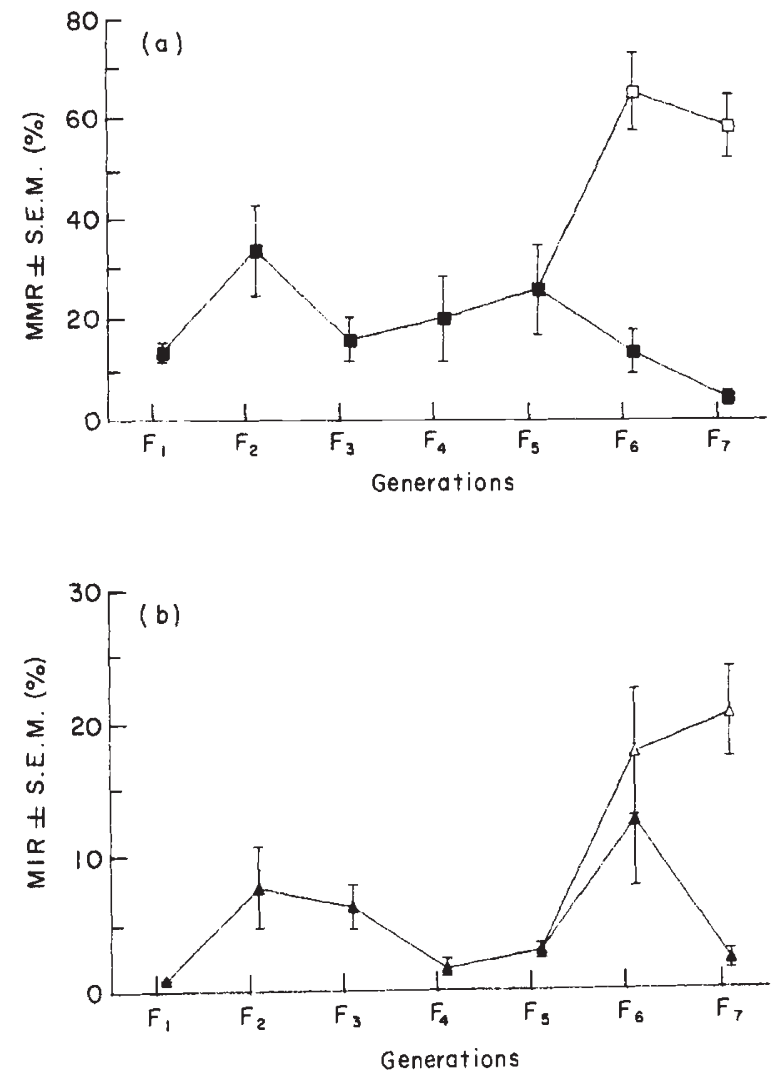

Fig. 1 Mean male ratio per progeny $(\mathrm{MMR})(\mathrm{a})$ and mean intersex ratio per progeny $(\mathrm{MIR})(\mathrm{b})$ in progenies of $(\boldsymbol{\square}, \mathbf{\Delta})$ TF and $(\square, \Delta)$ ARF neo-females, during the selection of TF and ARF traits.

of neo-females) was maintained in only about 20 per cent of the progenies of each generation. The mean male ratios per progeny (MMR) did not differ significantly from $F_{1}$ to $F_{5}(F=1.24$, d.f. $=4 ; 60)$. The impossibility of selecting a pure TF trait was due to the appearance in each generation of several progenies with a male rate of between 10 and 40 per cent, and at least one progeny with a male rate equal to or greater than 70 per cent (see for example generation $F_{5}$, Fig. 2).

Up to generation $F_{5}$, the ARF trait was selected from the progenies with more than 70 per cent males (Fig. 1). In $\mathrm{F}_{6}$, the difference between the MMR of TF and ARF strains was highly significant $(F=31.39$, d.f. $=1 ; 23)$. It was the same in $F_{7}$, where the MMR in the TF strain was 2.5 per cent \pm 1.4 , while in the ARF strain, $M M R=57.0$ per cent \pm 6.2 and the distribution of the male rates among progenies was more scattered (Fig. 3).

On the other hand, in progenies of the TF strain, the mean intersex ratio (MIR) never exceeded 12 per cent, while it was close to 20 per cent in progenies of the ARF strain (Fig. 1b). However, the difference between the MIR of these two strains was only significantly different in the $F_{7}$ generation $(F=35.52$, d.f. $=1 ; 31)$. These intersexes were typical of the strains harbouring $F$ bacteria. They were either individuals with a functional ovary and very small male external characters, or sterile individuals with developed male external characters and male or hermaphodite gonads (Legrand \& Juchault, 1986). No intersexes of the type 'neo-males with female genital apertures' were observed.

Moreover, 20 males from the TF and ARF strains of the $F_{6}$ generation were paired with genetic females (WZ) (Table 1). The sex ratio of their progenies was not significantly different from equilibrium $1: 1$ and no intersexes were observed.

\section{Inoculation experiments}

ARF neo-females of the $F_{6}$ generation and genetic females were inoculated with crushed ovaries from TF
Fig. 2 Distribution of progenies of TF neo-females of the $F_{5}$ generation of selection, as a function of their male percentage.

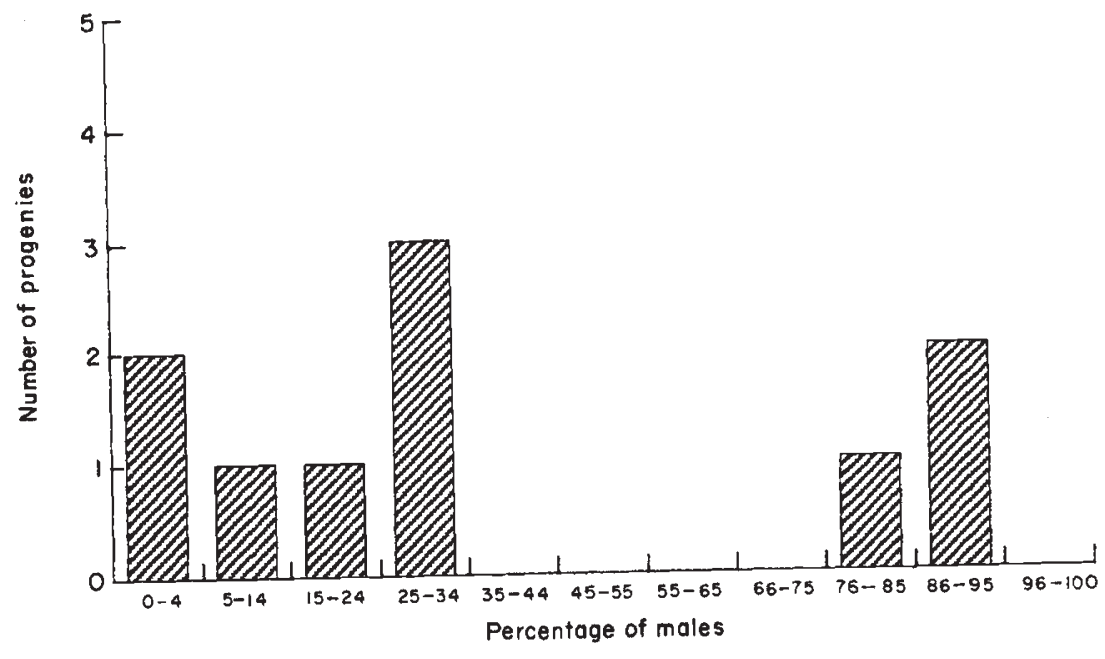




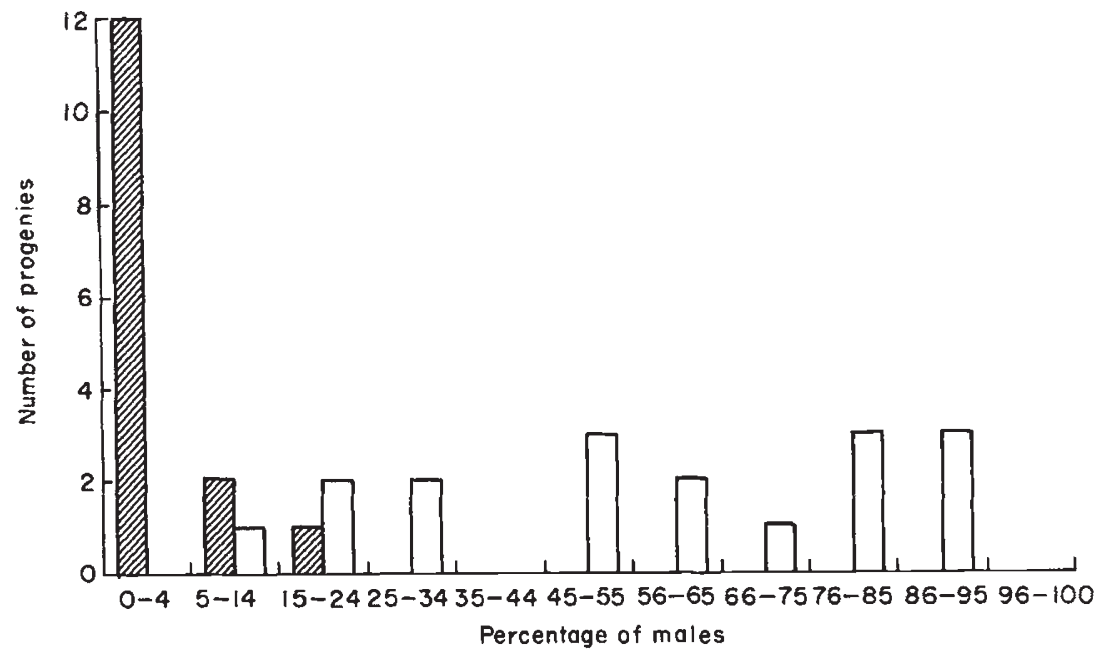

Fig. 3 Distribution of progenies of ( $(\square)$ TF and ( $\square$ ) ARF neo-females of the $F_{7}$ generation of selection, as a function of their male percentage.

Table 1 Mean male rate $(\mathrm{MMR}) \pm$ S.E.M. in progenies of genetic females $(\mathrm{WZ})$ mated with males from ARF and TF neofemales progenies

\begin{tabular}{llllll}
\hline Mating & $\begin{array}{l}\text { Number of } \\
\text { progenies }\end{array}$ & $\begin{array}{l}\text { Number of } \\
\text { males }\end{array}$ & $\begin{array}{l}\text { Total number } \\
\text { of offspring }\end{array}$ & $\begin{array}{l}\text { MMR } \pm \text { S.E.M. } \\
(\%)\end{array}$ & $F$-test \\
\hline OAR $\times$ \%WZ & 16 & 433 & 839 & $51.6 \pm 1.9$ & $0.26($ d.f. $=1 ; 34)$, ns \\
\hline $\mathrm{T} \times \$ \mathrm{WZ}$ & 19 & 584 & 1157 & $50.5 \pm 1.3$ & \\
\hline
\end{tabular}

Table 2 Mean male rates $(M M R) \pm$ S.E.M. in progenies of females inoculated with ovarian extracts from TF or ARF neo-females

\begin{tabular}{lll}
\hline \multirow{2}{*}{$\begin{array}{l}\text { Origin of the } \\
\text { ovarian extract }\end{array}$} & \multicolumn{2}{l}{ MMR in progenies of inoculated females } \\
\cline { 2 - 3 } & Genetic females $(\mathrm{WZ})$ & AR neo-females $(\mathrm{ZZ}+\mathrm{F})$ \\
\hline TF neo-females & $0.7 \% \pm 0.3$ & $64.9 \% \pm 13.1$ \\
ARF neo-females & $0.0 \%$ & $68.4 \% \pm 12.5$ \\
& $F=3.12$ (d.f. $=1 ; 33), \mathrm{ns}$ & $F=0.04($ d.f. $=1 ; 20), \mathrm{ns}$ \\
\hline
\end{tabular}

or ARF $F_{6}$ neo-females, then paired. Whatever the origin of the bacteria (TF or ARF neo-females), the inoculated genetic females always produced highly female-biased progenies, while most of the inoculated ARF neo-females produced arrhenogenous progenies (Table 2). In progenies of both categories of ARF neofemales (inoculated with bacteria from TF or ARF strains), the MMR were not different from the MMR value computed on progenies in the $\mathrm{F}_{7}$ generation of the ARF strain $(F=0.37$, d.f. $=1 ; 27$ for ARF neofemales inoculated with $\mathrm{TF}$ ovaries and $F=0.86$, d.f. $=1 ; 26$ for $\mathrm{ARF}$ neo-females inoculated with ARF ovaries).

\section{Discussion}

These results show that thelygenous (TF) and arrhenogenous (ARF) traits could be rapidly selected from a unique strain. The inoculation experiments show that, whatever the origin of inoculated bacteria, genetic females are unable to control the multiplication and the transmission of F, while a supply of bacteria in neofemales of the ARF strain does not increase their transmission to offspring. Thus it seems that the $F$ bacteria transmission depends on the genotype of the host and not on bacterial strains.

This genetic control is unrelated to the $M$ gene. No 
males of the ARF strain carry this gene, because the breeding of these males with WZ females gave a result that conforms with the homo-heterogametic composition of the genitors, and because no intersexes were observed in any broods. Moreover, no neo-males with female genital apertures were observed in progenies of the ARF strain (these individuals are typical of strains harbouring $M$ [Legrand et al., 1974]). Note that the ARF strain included more intersexes than the TF strain. These intersexes begin to differentiate the male sex, then this masculinizing phase stops and individuals evolve toward the female sex (Juchault, 1966). Thus, the feminizing effect of $\mathrm{F}$ bacteria occurs later in intersexes than in neo-females, allowing a more or less strong differentiation of the male sexual characters.

We put forward the following interpretation: the $F$ bacteria, whatever their origin, can potentially divide, spread and express their feminizing effect to every $A$. vulgare. However, some isopod genotypes (ARF) are able to control one or more of these phenomena. We cannot determine the precise level of this genetic control with the present data. It may involve a limitation of the number of bacteria, as in Sitophilus oryzae (Coleoptera) (Nardon \& Grenier, 1989) where a polygenic system with an additive effect controlling the symbiote density can be selected. A second hypothesis could be: the number of bacteria is the same in TF and ARF neo-females but their transmission rates to progenies are different. The host control could then act on endocytosis, which is the principal way involved in Rickettsial entry into host cells (Weiss, 1982; Tamura, 1988). Finally, the genetic control could act not on the bacteria themselves but rather prevent them from expressing their feminizing effect.

Whatever the mechanism involved, this genetic control corresponds to the 'resistance genes' defined by Werren (1987): 'genes influencing sex ratio indirectly via their effects on cytoplasmic factors', in contrast with the $M$ gene, which might correspond to both definitions of 'sex ratio genes' or 'sex determination genes' given by the same author.

As we failed to select a pure TF strain and the ARF trait was selected from a TF strain selected over many generations, we have to accept that genetic control depends on a polygenic system. Moreover, the variability of the response to selection (selected neofemales showing variable rates of males in their progenies) and the relatively high number of intersexes suggest that several genes that allow the multiplication or the transmission of $\mathrm{F}$ are still carried in the ARF strain.

In natural populations, the selection of these resistance genes ( $R$ genes) could be explained by con- sidering the entire evolution of sex-determining systems in $A$. vulgare, as described by Legrand et al. (1987) and Juchault \& Legrand (1989). Neo-females that produce ARF broods have only been observed in populations where genetic females have disappeared and where the F cytoplasmic sex factor is harboured by numerous individuals (Legrand et al., 1980; Juchault \& Legrand, 1981a). This stage is the final step in the evolution, after a total invasion of the sexual factors $F$ and $\mathrm{f}$ in populations (Legrand et al., 1987; Juchault \& Legrand, 1989). In such populations, arrhenogenous $\mathrm{ZZ}+\mathrm{F}$ or $\mathrm{ZZ}+\mathrm{f}$ neo-females are the only ones to produce a male rate high enough to enable reproduction (arrhenogeny could also have been observed in $\mathrm{ZZ}+\mathrm{f}$ neo-females). We have to imagine that, after the disappearance of the genetic females, neo-females capable of producing males are selected to avoid the extinction of the population. These neo-females carry either the $M$ gene or the $R$ genes. In this last case, such a selection would in theory induce a sex ratio close to $1: 1$ (Uyenoyama \& Feldman, 1978). Such a sex ratio is very rarely observed in natural populations, and only a few $\mathrm{ZZ}+\mathrm{F}$ neo-females carry resistance genes. In fact, the polygenic inheritance of the resistance would suggest that a sex ratio of $1: 1$ is very difficult to reach.

\section{References}

BULl, J. J. 1983. Evolution of Sex Determining Mechanisms. Benjamin/Cummings Publ. Co., Menlo Park, CA.

BULNHEIM, H. P. 1978. Interaction between genetic, external and parasitic factors in sex determination of the crustacean amphipod Gammarus duebeni. Helgol. Cuissens. Meer., 31, 1-33.

GINSBURGER-VOGEL, T., CARRE-LECUYER, M. AND FRIEDMONTAUFIER, M. C. 1980. Transmission expérimentale de la thélygénie liée à l'intersexualité chez Orchestia gammarellus (Pallas). Analyse des phénotypes sexuels dans les descendances de femelles normales transformées en femelles thélygènes. Arch. Zool. Exp. Gén., 122, 261-270.

IRVING-BELL, R. J. 1974. Cytoplasmic factors in the gonads of Culex pipiens complex mosquitoes. Life Sci., 14, 1149-1151.

JuChaUlt, P. 1966. Contribution à l'étude de la différenciation mâle chez les crustacés isopodes. Thèse de doctorat d'état, Université de Poitiers, France.

JUCHAULT, P. AND LEGRAND, J. J. 1972. Croisement de néo-mâles expérimentaux chez Armadillidium vulgare Latr. (Crustacé, Isopode, Oniscoide). Mise en évidence d'une hétérogamétie femelle. C.R. Acad. Sci. Paris, 274, 1387-1389.

JUCHAUlT, P. AND LEGRAND, J. J. 1976. Etude génétique de l'intersexualité des mâles à ouvertures génitales femelles chez l'oniscoïde Armadillidium vulgare Latr.: interpréta- 
tion et modalités de la transmission héréditaire. C.R. Soc. Biol., 2, 429-433.

JUCHAUlt, P. AND LEGRAND, J. J. 1981a. Contribution à l'étude qualitative et quantitative des facteurs contrôlant le sexe dans les populations du Crustacé Isopode terrestre Armadillidium vulgare Latr. II - Populations hébergeant le facteur féminisant $F$ (bactérie intracytoplasmique). Arch. Zool. Exp. Gén., 122, 65-74.

JUCHAUlT, P. AND LEGRAND, J. J. 1981b. Contribution à l'étude qualitative et quantitative des facteurs contrôlant le sexe dans les populations du Crustacé Isopode terrestre Armadillidium vulgare Latr. III - Populations n'hébergeant pas le facteur féminisant F. Arch. Zool. Exp. Gén., 122, 117-131.

JUCHAULT, P. AND LEGRAND, J. J. 1989. Sex determination and monogeny in terrestrial isopods Armadillidium vulgare (Latreille, 1804) and Armadillidium nasatum (BuddeLund, 1885). Monitore Zool. Ital. (N.S.) Monogr., 4, 359-375.

JUCHAULT, P., LEGRAND, J. J. AND MOCQUARD, J. P. 1980. Contribution à l'étude qualitative et quantitative des facteurs contrôlant le sexe dans les populations du Crustacé Isopode terrestre Armadillidium vulgare Latr. I - La population de Niort (Deux-Sèvres). Arch. Zool. Exp. Gén., 121, 3-27.

LARSSON, R. 1983. A rickettsia-like microorganism similar to Wolbachia pipiensis and its occurrence in Culex mosquitoes. J. Inv. Path., 41, 387-390.

LEGRAND, J. J. AND JUCHAULT, P. 1970. Contrôle de la sexualité chez les crustacés isopodes gonochoriques et hermaphrodites. Bull. Soc. Zool. Fr., 95, 551-553.

LEGRAND, J. J. AND JuCHAULT, P. 1984. Nouvelles données sur le déterminisme génétique et épigénétique de la monogénie chez le crustacé isopode terrestre Armadillidium vulgare Latr. Gén. Sél. Evol., 16, 57-84.

LEGRAND, J. J., JUCHAULT, P. AND MOCQUARD, J. P. 1974. Analyse préliminaire de l'intersexualité féminisante chez le crustacé Armadillidium vulgare Latr. (isopode oniscoïde). C.R. Acad. Sci. Paris., 278, 2979-2982.
LEGRAND, J. J., LEGRAND-HAMELIN, E. AND JUCHAULT, P. 1987. SeX determination in crustacea. Biol. Rev., 62, 439-470.

MARTIN, G., JUCHAULT, P., LEGRAND, J. J. 1973. Mise en évidence d'un microorganisme intracytoplasmique symbiote de l'Oniscoïde Armadillidium vulgare L., dont la présence accompagne l'intersexualité ou le féminisation totale des mâles génétiques de la lignée thélygène. C.R. Acad. Sci. Paris, 276, 2312-2316.

MOCQUARD, J. P., JUCHAULT, P. AND SOUTY-GROSSET, C. 1989. The role of environmental factors (temperature and photoperiod) in the reproduction of the terrestrial isopod Armadillidium vulgare (Latreille, 1804). Monitore Zool. Ital. (N.S.) Monogr., 4, 455-475.

NARDON, P. AND GRENIER, A. M. 1989. Endocytobiosis in coleoptera: biological biochemical and genetic aspects. In: Insect Endocytobiosis: Morphology, Physiology, Genetics, Evolution, CRC Press, Inc., Boca Raton, Florida, pp. 175-216.

Rigaud, T., JUChault, P. AND Mocouard, J. P. (1991). Experimental study of temperature effects on sex ratio of broods in terrestrial crustacea Armadillidium vulgare Latr. Possible implication in natural populations. $J$ Evol. Biol. (in press).

SKINNER, S. W. 1983. Extrachromosomal sex ratio factors in the parasitoid wasp, Nasonia (=Mormoniella) vitripennis. Ph.D., University of Utah, Salt Lake City.

TAMURA, A. 1988. Invasion and intracellular growth of Rickettsia tsutsugamushi. Microbiol. Sci., 5, 228-238.

UYENOYAMA, M. K. AND FELDMAN, L. W. 1978. The genetics of sex ratio distortion by cytoplasmic infection under maternal and contagious transmission: an epidemiological study. Theor. Pop. Biol., 14, 471-497.

WEISS, E. 1982. The biology of rickettsiae. Ann. Rev. Microbiol., 36, 345-370.

WERREN, J. H. 1987. The coevolution of autosomal and cytoplasmic sex ratio factors. J. Theor. Biol., 124, 317-334.

WERREN, J. H., SKINNER, S. W. AND CHARNOV, E. L. 1981. Paternal inheritance of a daughterless sex ratio factor. Nature, 293, 467-468. 